\title{
Management of Post Endoscopic Retrograde Cholangiopancreatography (ERCP) Complications
}

\author{
AYMAN H. IBRAHIM, M.D.; MOHAMMAD M. SALEM, M.D. and \\ MUHAMMAD A. MOBASHER ATIYA, M.Sc. \\ The Department of General Surgery, Faculty of Medicine, Al-Azhar University
}

\begin{abstract}
Background: Endoscopic retrograde cholangiopancreatography (ERCP) is considered as a diagnostic and therapeutic procedure used to treat problems associated with biliary and pancreatic diseases. The benefits of ERCP over surgical treatment are well documented; however, there is complications including infection, pancreatitis, hemorrhage, and perforation can occur even in expert hands. Several factors may affect, such as patient selection, skills of the operator, and the how complex the procedure was. This work studies ERCP complication rates, predictive factors for incidence and management plans to improve outcomes.
\end{abstract}

Aim of Study: To spot complications that happened postERCP and how to manage it.

Patients and Methods: In a prospective, 2-years study from September 2017 to September 2019 of 50 patients underwent ERCP and notice if complications happened and the risk factors for that complication.

Results: $20 \%$ had post-ERCP complications, with pancreatitis $(8 \%)$, perforation $(8 \%)$ and infection (cholangitis and cholecystitis) (4\%). Perforation was considered the most serious complication of ERCP. It demands early diagnosis and good management. Surgical intervention the urgent solution to manage post-ERCP perforation ( 3 of the 4 perforated patients underwent surgical intervention.

Conclusion: ERCP is a safe and widely used all over the world. To overcome its complications it demands good preparation for patients, increase our experience, short procedure especially in risky patients, and close observation post-ERCP patients aiming at early diagnosis of complications and early management if happened.

Key Words: ERCP - Post-ERCP perforation - ERCP complications.

\section{Introduction}

SINCE 1968 ERCP are widely used and considered a very important technique in diagnosis and management of postoperative hepatobiliary surgerical complications and to manage pancreaticobiliary disorders too [1]. However ERCP has complications

Correspondence to: Dr. Ayman H. Ibrahim, E-Mail: aymanmohamedmed.b@azhar.edu.eg as perforation the most serious one, pancreatitis the most common one, bleeding, infection as cholangitis and cholecystitis [2]. There is high mortality rate from perforation post-ERCP thus it demands good urgent management that include early diagnosis and early surgical intervention aiming to save the patient life [3]

\section{Aim of the study:}

This study aims at detection of ERCP complication, especially perforation, studying factors that affect incidence and management with assessment of surgical repair outcomes.

\section{Indications of ERCP:}

It has many indications as: (A) Biliary tract disorders (malignancy, common bile duct stones, iatrogenic biliary injury and acute cholangitis) [4] (B) Pancreatic disorders (Acute biliary pancreatitis, chronic pancreatitis, pancreatic duct stone or stricture and pancreatic pseudo cyst) [5] . (C) Ampullary disorders (biopsy, sphincter of Oddi manommetry and dysfunction) [6]

\section{Contraindications of ERCP:}

Upper gastrointestinal tract abnormalities, uncorrectable coagulopathy, respiratory failure. Acute pancreatitis is a controversy for ERCP as many studies done on many patients that advice ERCP in the acute phase of gall stone pancreatitis with remarkable safety. It is usually easy to remove small impacted stones with impressive clinical recovery concluding that sphincterotomy prevent recurrent gall stone pancreatitis when the gall bladder is left in situ $[\mathbf{6 , 7 , 8 ]}$.

\section{Patients and Methods}

This study was conducted on 50 patients, who were admitted at Al-Galaa Military Hospital, and Al-Hussein University Hospital from September 2017 to September 2019 applied for ERCP. 
The following data for all patients were collected and reported in a special standard sheet designed for all patients before the procedure:

- Patients' demographics; age, sex, general condition.

- Complete history taking with special emphasis on history of risk factors, medical diseases (diabetes, hypertension and liver cirrhosis) and drugs taken by the patient (e.g. anticoagulants, prophylactic antibiotics). Thorough clinical examination.

- Various blood tests including: (Complete blood count, Baseline serum amylase and lipase, Liver profile including: ALT, AST, total and direct bilirubin, alkaline phosphatase, gamma glutamyltranspeptidase, Prothrombin time, INR and Kidney function tests).

- Imaging studies (abdominal ultrasonography U/S, abdominal CT scan and when indicated \& ECG).

\section{Before the procedure:}

All patients were fasted for at least 6 hours, all signed an informed written consent before the procedures, after receiving an explanation of the risks, benefits and alternatives of ERCP and associated therapeutic procedures.

Prophylactic antibiotics were not routinely given to all patients but antibiotic prophylaxis is recommend for endoscopic procedures of the patients at high risk of endocarditis or of symptomatic bacteremia as a consequence of immunodeficiency or neutropenia, better use of parenteral amoxicillin and gentamycin is recommended with addition of metronidazole especially in patients with neutropenia [13]

\section{During the procedure:}

The procedure was performed under sedation with propofol or with intravenous midazolam and pethidine. Duodenal relaxation was induced with intravenous hyoscine $\mathrm{N}$-butyl bromide, and blood oxygen saturation was monitored by using pulse oximeter during the procedure. All procedures were performed using standard duodenoscopes. Biliary sphincterotomy was performed using a standard manner with the use of a variety of papillotomes. Stones were extracted with retrieval balloons or Dormia baskets after mechanical lithotripsy when necessary. Biliary stents were placed when indicated. Bile duct diameter will be measured and any stricture will be reported. During the procedure, all endoscopic data and any adverse event or complication occurred was reported.

\section{After the procedure:}

All outpatients were observed for a minimum of 2 hours in the recovery room of the ERCP unit and any complications observed during the recovery period were recorded. Patients were discharged from the ERCP unit if there is no evidence of pain, fever, unstable vital signs, or prolonged sedation.

\section{Follow-up:}

Follow-up by bedside visits the day after ERCP and contact with the inpatients was maintained after discharge. Measurement of serum amylase, complete blood count, liver function tests and kidney function tests 24 hours after ERCP. All patients and their relatives were given detailed instructions about symptoms of post-ERCP complications and informed to contact us by phone or to come to the emergency room or outpatient clinic if any symptoms suggestive of post-ERCP complications developed. The patients were followed after being discharged from the hospital until a completion of 30 days after ERCP. Follow up of risky previously admitted patients is monitored by laboratory tests and investigations to predict complications early. In cases of complications, management was recorded conservative or surgical intervention.

Follow-up of all patients was done after discharge and close observation for those who had surgical interventions due to ERCP procedure up to 6 months post-ERCP.

\section{Statistical analysis:}

Collected data analysis was performed by independent statistician using statistical package for social sciences, version 20.0 (SPSS Inc., Chicago, Illinois, USA). Mean \pm standard deviation (SD) values were used to express quantitative data while percentages and frequencies were used to measure qualitative data.

\section{The following tests were done:}

- Independent-samples $t$-test of significance was used when comparing between two means.

- Chi-square $\left(\mathrm{X}^{2}\right)$ test of significance was used in order to compare proportions between qualitative parameters.

- The confidence interval was set to $95 \%$ and the margin of error accepted was set to 5\%. So, the $p$-value was considered significant as the following:

- Probability ( $p$-value).

- $p$-value $\leq 0.05$ was considered significant.

- $p$-value $\leq 0.001$ was considered as highly significant.

- $p$-value $>0.05$ was considered insignificant. 


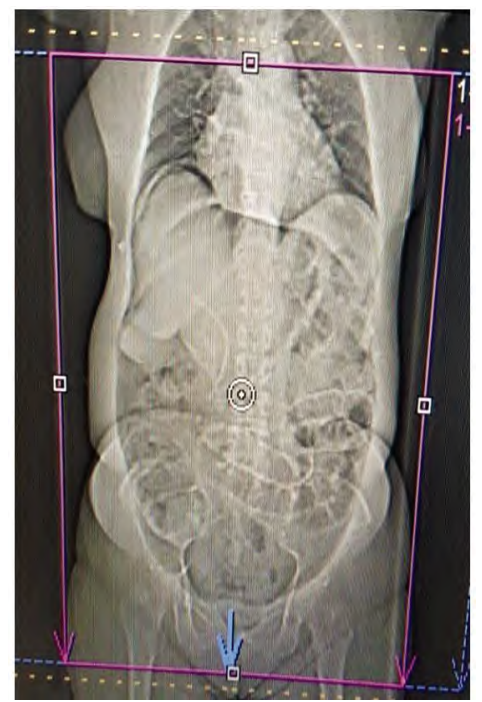

Fig. (1): X-ray showing gas under diaphragm post-ERCP.

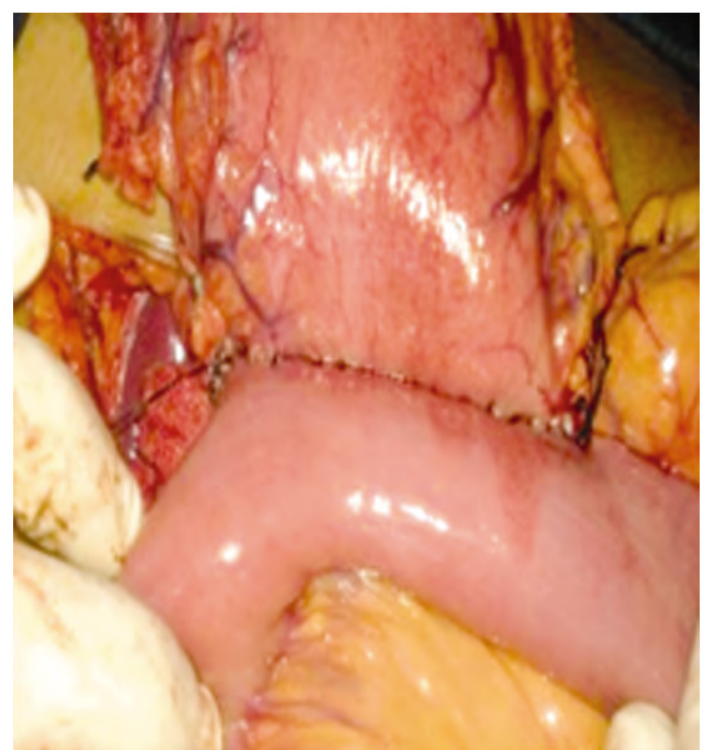

Fig. (3): Gastro jejnostomy post-ERCP perforation.

\section{Results}

This study was performed on 50 adult patients. It included 31 (62.0\%) females and 19 (38.0\%) males ranging from 25-70 yeas with mean age of $54.38 \pm 11.84$ years. Statistical analysis of demographic data of participating patient was done. Statistically significant difference in means of age (increase in non-complication group), HTN and DM (increase in complication). Results of demographic data were demonstrated in Table (1).

Pre and post-ERCP serum amylase levels showed statistically significant increase mean of Post-ERCP levels in complication group compared to non-complication group as illustrated in Table (2).

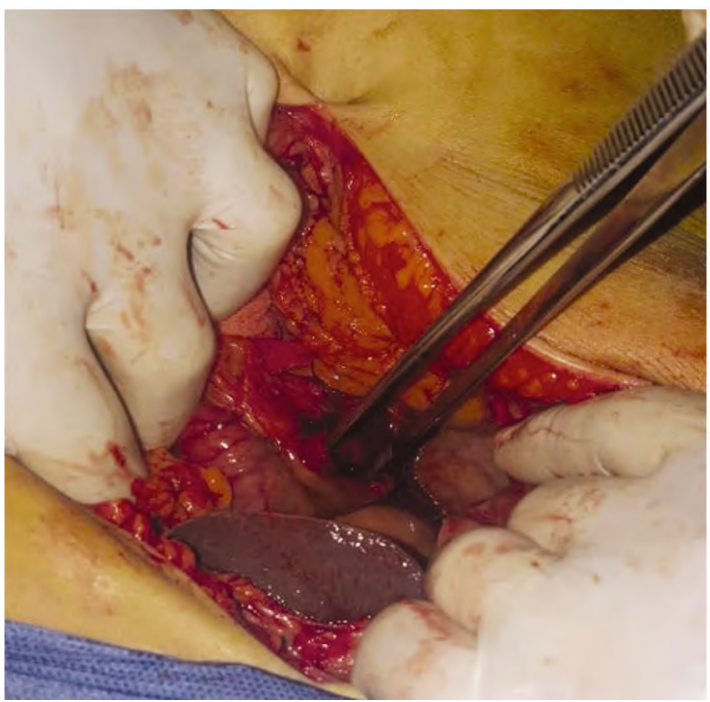

Fig. (2): Perforation post-ERCP.

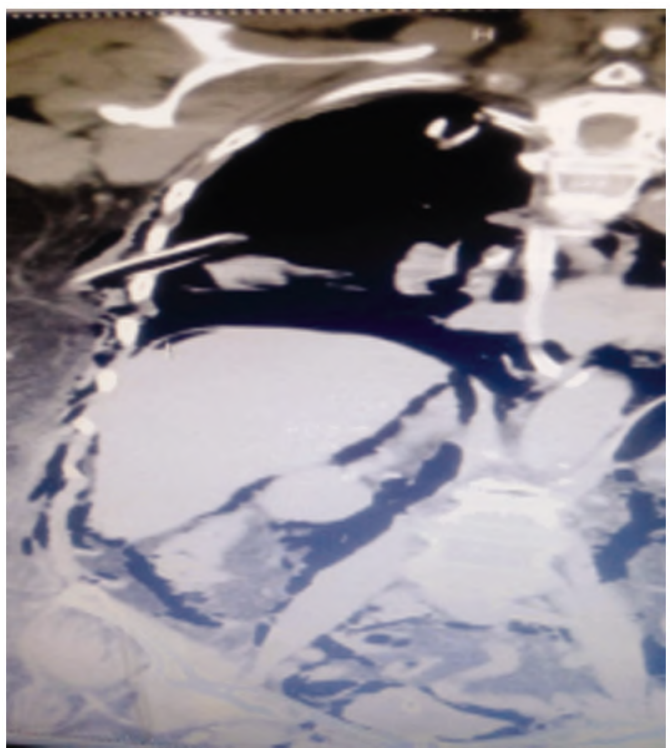

Fig. (4): Showing retro peritoneal dudonal perforation.

Similarly, significant increase in post-ERCP serum lipase monitored levels (Table 3 ) in complication group.

The relation between Non-complication and post-ERCP complication groups according to radiological finding is illustrated in Fig. (5).

Positive ERCP findings had been compared in both ERCP complication and non-complication groups. The work revealed statistically significant differences between the studied groups as found in Table (4). Complication rates and types in the study are presented in Table (5).

The study also defined a statistically significant difference between the compared groups as regard post-ERCP surgery. The varieties of surgical interventions were shown in Table (6). 
Table (1): Comparison between non-complication and post ERCP complications according to demographic data.

\begin{tabular}{|c|c|c|c|c|c|}
\hline Demographic data & $\begin{array}{l}\text { Total } \\
(\mathrm{n}=50)\end{array}$ & $\begin{array}{l}\text { Non-Complication } \\
\qquad(\mathrm{n}=40)\end{array}$ & $\begin{array}{c}\text { Post-ERCP } \\
\text { Complications }(\mathrm{n}=10)\end{array}$ & $X^{2}$ & $p$-value \\
\hline \multicolumn{6}{|l|}{ Age (years): } \\
\hline Mean \pm SD & $54.38 \pm 11.84$ & $52.15 \pm 12.11$ & $63.30 \pm 4.22$ & $t=8.12$ & $0.006^{*}$ \\
\hline Range & $25-70$ & $25-68$ & $58-70$ & & \\
\hline \multicolumn{6}{|l|}{ Sex: } \\
\hline Female & $31(62.0 \%)$ & $23(57.5 \%)$ & $8(80.0 \%)$ & 1.719 & 0.190 \\
\hline Male & $19(38.0 \%)$ & $17(42.5 \%)$ & $2(20.0 \%)$ & & \\
\hline \multicolumn{6}{|l|}{ Smoking: } \\
\hline No & $37(74.0 \%)$ & $29(72.5 \%)$ & $8(80.0 \%)$ & 0.234 & 0.629 \\
\hline Yes & $13(26.0 \%)$ & $11(27.5 \%)$ & $2(20.0 \%)$ & & \\
\hline \multicolumn{6}{|l|}{ HTN: } \\
\hline No & $35(70.0 \%)$ & $31(77.5 \%)$ & $4(40.0 \%)$ & 5.357 & $0.021^{*}$ \\
\hline Yes & $15(30.0 \%)$ & $9(22.5 \%)$ & $6(60.0 \%)$ & & \\
\hline \multicolumn{6}{|l|}{$D M:$} \\
\hline No & $39(78.0 \%)$ & $35(87.5 \%)$ & $4(40.0 \%)$ & 10.519 & $<0.001 * *$ \\
\hline Yes & $11(22.0 \%)$ & $5(12.5 \%)$ & $6(60.0 \%)$ & & \\
\hline \multicolumn{6}{|l|}{ Previous operation: } \\
\hline No & $37(74.0 \%)$ & $28(70.0 \%)$ & $9(90.0 \%)$ & 1.663 & 0.197 \\
\hline Yes & $13(26.0 \%)$ & $12(30.0 \%)$ & $1(10.0 \%)$ & & \\
\hline \multicolumn{6}{|l|}{$H C V:$} \\
\hline No & $37(74.0 \%)$ & $30(75.0 \%)$ & $7(70.0 \%)$ & 0.104 & 0.747 \\
\hline Yes & $13(26.0 \%)$ & $10(25.0 \%)$ & $3(30.0 \%)$ & & \\
\hline
\end{tabular}

Using: Independent Sample $t$-test. $\quad \# \mathrm{X}^{2}$ : Chi-square test $p$-value $>0.05 \mathrm{NS} . \quad * p$-value $<0.05 \mathrm{~S} . \quad * * p$-value $<0.001 \mathrm{HS}$.

Table (2): Comparison between non-complication and post-ERCP complications according to serum amylase (u/l).

\begin{tabular}{|c|c|c|c|c|c|}
\hline Amylase (u/l) & $\begin{array}{c}\text { Total } \\
(\mathrm{n}=50)\end{array}$ & $\begin{array}{l}\text { Non-Complication } \\
\qquad(\mathrm{n}=40)\end{array}$ & $\begin{array}{c}\text { Post-ERCP } \\
\text { Complications }(n=10)\end{array}$ & $t$-test & $p$-value \\
\hline \multicolumn{6}{|l|}{ Pre: } \\
\hline Mean \pm SD & $74.54 \pm 18.21$ & $74.38 \pm 17.03$ & $75.20 \pm 23.41$ & 0.016 & 0.900 \\
\hline Range & $38-123$ & $49-123$ & $38-98$ & & \\
\hline \multicolumn{6}{|l|}{ Post: } \\
\hline Mean \pm SD & $200.14 \pm 215.06$ & $114.70 \pm 12.07$ & $541.90 \pm 298.27$ & 86.908 & $<0.001 * *$ \\
\hline Range & $94-1058$ & $94-139$ & $190-1058$ & & \\
\hline
\end{tabular}

Using: Independent Sample $t$-test. $\quad p$-value $>0.05$ NS. $\quad * * p$-value $<0.001$ HS.

Table (3): Comparison between non-complication and post-ERCP complications according to lipase.

\begin{tabular}{|c|c|c|c|c|c|}
\hline Lipase (u/L) & $\begin{array}{l}\text { Total } \\
(n=50)\end{array}$ & $\begin{array}{l}\text { Non-Complication } \\
\qquad(\mathrm{n}=40)\end{array}$ & $\begin{array}{c}\text { Post-ERCP } \\
\text { Complications }(n=10)\end{array}$ & $t$-test & $p$-value \\
\hline \multicolumn{6}{|l|}{ Pre: } \\
\hline Mean \pm SD & $74.54 \pm 18.21$ & $74.38 \pm 17.03$ & $75.20 \pm 23.41$ & 2.579 & 0.115 \\
\hline Range & $38-123$ & $49-123$ & $38-98$ & & \\
\hline \multicolumn{6}{|l|}{ Post: } \\
\hline Mean \pm SD & $200.14 \pm 215.06$ & $114.70 \pm 12.07$ & $541.90 \pm 298.27$ & 120.440 & $<0.001 * *$ \\
\hline Range & 94-1058 & $94-139$ & $190-1058$ & & \\
\hline
\end{tabular}

Using: Independent Sample $t$-test. $\quad * * p$-value $>0.05$ NS. $* * * p$-value $<0.001 \mathrm{HS}$. 


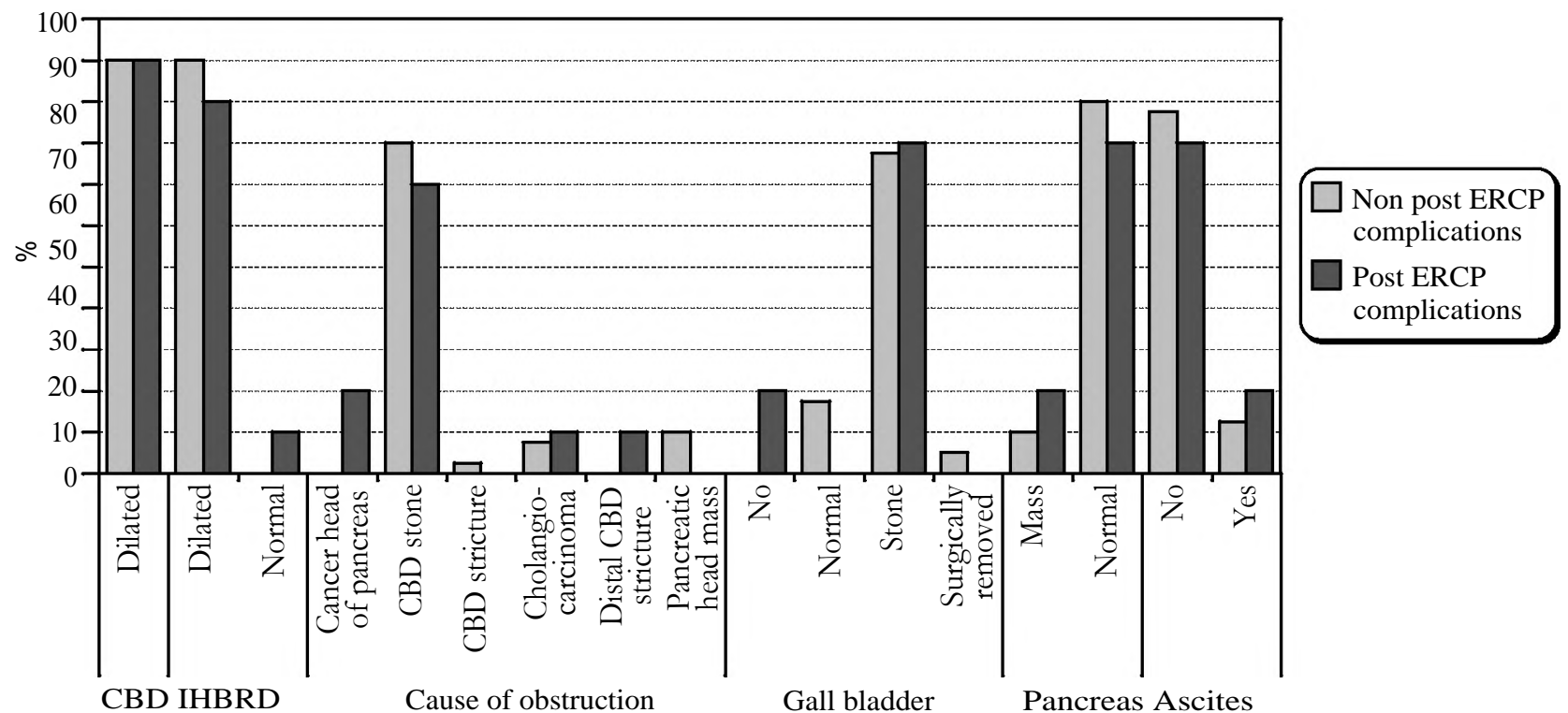

CBD IHBRD Cause of obstruction $\quad$ Gall bladder Pancreas Ascites
Fig. (5): Bar chart between non-complication and post-ERCP Complications according to radiological finding.

Table (4): Comparison between non-complication and Post-ERCP complications according to ERCP findings in studied groups.

\begin{tabular}{|c|c|c|c|c|c|}
\hline $\begin{array}{l}\text { ERCP findings in } \\
\text { studied groups }\end{array}$ & $\begin{array}{c}\text { Total } \\
(\mathrm{n}=50)\end{array}$ & $\begin{array}{l}\text { Non-Complication } \\
\qquad(\mathrm{n}=40)\end{array}$ & $\begin{array}{c}\text { Post-ERCP } \\
\text { Complications }(n=10)\end{array}$ & $X^{2}$ & $p$-value \\
\hline \multicolumn{6}{|l|}{ Stone: } \\
\hline Failed & $4(8.0 \%)$ & $0(0.0 \%)$ & $4(40.0 \%)$ & 18.421 & $<0.001 * *$ \\
\hline No & $8(16.0 \%)$ & $8(20.0 \%)$ & $0(0.0 \%)$ & & \\
\hline Yes & $38(76.0 \%)$ & $32(80.0 \%)$ & $6(60.0 \%)$ & & \\
\hline \multicolumn{6}{|l|}{ Stricture: } \\
\hline Failed & $4(8.0 \%)$ & $0(0.0 \%)$ & $4(40.0 \%)$ & 17.399 & $<0.001 * *$ \\
\hline No & $39(78.0 \%)$ & $34(85.0 \%)$ & $5(50.0 \%)$ & & \\
\hline Yes & $7(14.0 \%)$ & $6(15.0 \%)$ & $1(10.0 \%)$ & & \\
\hline \multicolumn{6}{|l|}{ Mass: } \\
\hline Failed & $4(8.0 \%)$ & $0(0.0 \%)$ & $4(40.0 \%)$ & 17.988 & $<0.001 * *$ \\
\hline No & $41(82.0 \%)$ & $35(87.5 \%)$ & $6(60.0 \%)$ & & \\
\hline Yes & $5(10.0 \%)$ & $5(12.5 \%)$ & $0(0.0 \%)$ & & \\
\hline
\end{tabular}

Using: $\mathrm{X}^{2}$ : Chi-square test. $\quad * * p$-value $<0.001 \mathrm{HS}$.

Table (5): Comparison between non-complication and Post-ERCP complications according to complications.

\begin{tabular}{|c|c|c|c|c|c|}
\hline Complications & $\begin{array}{l}\text { Total } \\
(\mathrm{n}=50)\end{array}$ & $\begin{array}{l}\text { Non-Complication } \\
\qquad(\mathrm{n}=40)\end{array}$ & $\begin{array}{c}\text { Post-ERCP } \\
\text { Complications }(\mathrm{n}=10)\end{array}$ & $X^{2}$ & $p$-value \\
\hline $\begin{array}{l}\text { Chelcystitis } \\
\text { First part of duodenum perforation } \\
\text { Pancreatits } \\
\text { Pyloric injury } \\
\text { Retro dudonal perforation } \\
\text { No }\end{array}$ & $\begin{array}{l}2(4.0 \%) \\
2(4.0 \%) \\
4(8.0 \%) \\
1(2.0 \%) \\
1(2.0 \%) \\
40(80.0 \%)\end{array}$ & $\begin{array}{l}0(0.0 \%) \\
0(0.0 \%) \\
0(0.0 \%) \\
0(0.0 \%) \\
0(0.0 \%) \\
40(100.0 \%)\end{array}$ & $\begin{array}{l}2(20.0 \%) \\
2(20.0 \%) \\
4(40.0 \%) \\
1(10.0 \%) \\
1(10.0 \%) \\
0(0.0 \%)\end{array}$ & 50.000 & $<0.001 * *$ \\
\hline $\begin{array}{l}\text { Management: } \\
\text { Conserve } \\
\text { Operation } \\
\text { No }\end{array}$ & $\begin{array}{l}7(14.0 \%) \\
3(6.0 \%) \\
40(80.0 \%)\end{array}$ & $\begin{array}{l}0(0.0 \%) \\
0(0.0 \%) \\
40(100.0 \%)\end{array}$ & $\begin{array}{l}7(70.0 \%) \\
3(30.0 \%) \\
0(0.0 \%)\end{array}$ & 50.000 & $<0.001 * *$ \\
\hline $\begin{array}{l}\text { Follow-up after discharge: } \\
\text { Cholecystectomy done } \\
\text { Pseudo Pancreatic cyst and } \\
\text { cyst gastrostomy done } \\
\text { No }\end{array}$ & $\begin{array}{l}31(62.0 \%) \\
1(2.0 \%) \\
18(36.0 \%)\end{array}$ & $\begin{array}{l}31(77.5 \%) \\
0(0.0 \%) \\
92(2.5 \%)\end{array}$ & $\begin{array}{l}0(0.0 \%) \\
1(10.0 \%) \\
9(90.0 \%)\end{array}$ & 21.875 & $<0.001 * *$ \\
\hline
\end{tabular}

Using: $\mathrm{X}^{2}$ : Chi-square test. $* * p$-value $<0.001 \mathrm{HS}$. 
Table (6): Comparison between non-complication and post-ERCP complications according to surgery.

\begin{tabular}{|c|c|c|c|c|c|}
\hline Surgery & $\begin{array}{c}\text { Total } \\
(\mathrm{n}=50)\end{array}$ & $\begin{array}{l}\text { Non-Complication } \\
\qquad(\mathrm{n}=40)\end{array}$ & $\begin{array}{c}\text { Post-ERCP } \\
\text { Complications }(n=10)\end{array}$ & $X^{2}$ & $p$-value \\
\hline \multicolumn{6}{|l|}{ Surgery: } \\
\hline No & $46(92.0 \%)$ & $40(100.0 \%)$ & $6(60.0 \%)$ & 27.273 & $<0.001 * *$ \\
\hline Yes & $4(8.0 \%)$ & $0(0.0 \%)$ & $4(40.0 \%)$ & & \\
\hline \multicolumn{6}{|l|}{$\begin{array}{l}\text { Type of Surgery due to ERCP } \\
\text { complications: }\end{array}$} \\
\hline $\begin{array}{l}\text { Cholecysto -jejnestomy and } \\
\text { jejno-jujnostomy }\end{array}$ & $1(2.0 \%)$ & $0(0.0 \%)$ & $1(10.0 \%)$ & 32.558 & $<0.001 * *$ \\
\hline $\begin{array}{l}\text { Cholecystojejuno Stomy \& } \\
\text { jejunojejuno Stomy and } \\
\text { gastrojejuno Stomy }\end{array}$ & $1(2.0 \%)$ & $0(0.0 \%)$ & $1(10.0 \%)$ & & \\
\hline Cyst gastrostomy & $1(2.0 \%)$ & $0(0.0 \%)$ & $1(10.0 \%)$ & & \\
\hline $\begin{array}{l}\text { Pyloric exclusion and } \\
\text { gastro jejnostomy }\end{array}$ & $1(2.0 \%)$ & $0(0.0 \%)$ & $1(10.0 \%)$ & & \\
\hline No & $46(92.0 \%)$ & $40(100.0 \%)$ & $6(60.0 \%)$ & & \\
\hline
\end{tabular}

Using: $\mathrm{X}^{2}$ : Chi-square test. *** $p$-value $<0.001 \mathrm{HS}$.

\section{Discussion}

The overall complication rate in the present study was $20 \%$; post-ERCP perforation in $8 \%$, pancreatitis occurred in $8 \%$, Cholecystitis $2 \%$ and cholangitis $2 \%$.

Reported increase in complication rates was observed in cases with co-morbidities, HTN and DM. Controversially, there was recorded decline in complications with age. This high rates of complications may be over estimating to the problem, explained by selection of small number of cases for the study. Further work on larger samples is required to assess reliability of the study outcomes.

Many western studies showed that the rate of short-term complications reported was 5\% to $15.9 \%$ of ERCPs with or without sphincterotomy. Masci et al., study on 2462 patient to determine the risk factors for pot diagnostic and therapeutic ERCP unfavorable complications described an overall complication rate of $4.95 \% ; 1.8 \%$ had pancreatitis, $1.13 \%$ had hemorrhages, $0.57 \%$ with cholangitis and $0.57 \%$ showed duodenal perforations. Mortality rate of $0.12 \%$ (3 patients) was reported in the study. Significant pancreatitis risk factors were age $>60$ years, precutting technique usage and failure of clearing stone clearance. Risk of incidence of hemorrhage was more in cases of precut sphincterotomy techniques and papilla obstruction [13].

Significant increase mean of post-ERCP levels of serum amylase and lipase in complication group denotes the importance of post procedural followup by both clinical and laboratory tests that may predict complications especially acute pancreatitis.
The study of Iorgulescu et al., at 2013 included 900 patients investigating post-ERCP acute pancreatitis. They stated that by far, the commonest complication after ERCP was acute pancreatitis which occurred in $3.7 \%$. Bleeding and perforation were revealed in $1.04 \%$ and $0.69 \%$ respectively. They defined the difficult sphincterotomy, use of precut method, failure of CBD clearance, pancreatic sphincterotomy and repeated contrast injection as risk factors for its post-ERCP pancreatitis [14]

There was a relation between abnormal finding in biliary system on imaging (U/S-CT scan-MRCP) and post-ERCP complication. So, if detected, noninvasive investigations as MRCP are recommended and ERCP should be avoided.

Complications vary with endoscopic expertise, intended level of therapy, or use of preventative techniques such as placement of pancreatic stents to reduce risk of pancreatitis [15].

Higher rate of overall complications in the present study can be also attributed to that the endoscopists who participated in the present study used variable techniques and ERCP units which shared in the present study did not necessitate inserting a pancreatic stent in high risk patients as a routine. Reported that pancreatic stent placement has been shown to be the most effective technique to prevent post-ERCP pancreatitis [15]

Patients with positive ERCP findings had been found to have more complications than those with normal ERCP. So, in the present study which showed similar significance, there was significant difference in the complication rate between therapeutic ERCP. This finding is consistent with that 
of a retrospective survey by [12], but was in contrast with those from a British survey by [13] and an Italian study by [14] in which therapeutic ERCP was associated with three to four-folds higher complication rates.

In the present study, the duration of procedure was found to be a risk factor in univariate analysis for occurrence of overall complications of the study. When the duration of the procedure was 3060 minutes, the risk of complications was $5.6 \%$, when the procedure lasted from $>60$ minutes, the risk was $31.8 \%$ and the risk of overall complications reached.

\section{Conclusion:}

ERCP plays an important role in the management of patients with a variety of biliary and pancreatic disorders. ERCP complications can and do occur even when a well skilled endoscopist is involved and all relevant guidelines and studies are adhered to. Endoscopists need to be a doctor aware of ERCP complications and be proactive in its diagnosis and management. Surgery decisionmaking should be in mind if required to manage a complication. Endoscopy centers should have a well quality assurance programs to track any negative outcomes prospectively so that issues that demand intervention can be identified. More work on larger samples is needed to get more reliability and evidence-based data that help in the recognition of risk factors for post-ERCP complications.

\section{References}

1- FREEMAN M.L., NELSON D.B., SHERMAN S., et al.: Complications of endoscopic biliary sphincterotomy. $\mathrm{N}$. Engl. J. Med., 335 (13): 909-18, 2016.

2- WANG P., LI Z.S., LIU F., et al.: Risk factors for ERCPrelated complications: A prospective multicenter study. Am. J. Gastroenterol., 104 (1): 31-40, 2018.

3- WILLIAMS E.J., TAYLOR S., FAIRCLOUGH P., et al.: Risk factors for complication following ERCP; results of a large-scale, prospective multicenter study. Endoscopy, 39 (9): 793-801, 2017.

4- ANDRIULLI A., LOPERFIDO S., NAPOLITANO G., et al.: Incidence rates of post-ERCP complications: A systematic survey of prospective studies. Am. J. Gastroenterol., 102 (8): 1781-88, 2017.

5- ELMUNZER B.J., SCHEIMAN J.M., LEHMAN G.A., et al.: A randomized trial of rectal indomethacin to prevent post-ERCP pancreatitis. N. Engl. J. Med., 366 (15): 141422, 2012.

6- PAHK A., RIGAUX J., POREDDY V., et al.: Prophylactic pancreatic stents: Does size matter? A comparison of 4Fr and 5-Fr stents in reference to post-ERCP pancreatitis and migration rate. Dig. Dis. Sci., 56 (10): 3058-3064, 2015.

7- Cheng C.L., Sherman S., Watkins J.L., et al.: Risk factors for post-ERCP pancreatitis: A prospective multicenter study. Am. J. Gastroenterol., 101 (1): 139-147, 2016.

8- CLASSEN D.C., JACOBSON J.A., BURKE J.P., et al.: Serious Pseudomonas infections associated with endoscopic retrograde cholangiopancreatography. Am. J. Med., 84 (3 pt 2): 590-596, 2018.

9- PARKER H.W., GREENEN J.E., BJORK J.T., et al.: A prospective analysis of fever and bacteraemia following ERCP. Gastrointest Endosc., 25 (3): 102-103, 2013.

10- KULLMAN E., BORCH K., LINDSTRQM E., et al.: Bacteremia following diagnostic and therapeutic ERCP. Gastrointest Endosc., 38 (4): 444-449, 2012.

11- SUBHANI J.M., KIBBLER C. and DOOLEY J.S.: Review article: Antibiotic prophylaxis for endoscopic retrograde cholangiopancreatography (ERCP). Aliment Pharmacol. Ther., 13 (2): 103-116, 2016.

12- LOPERFIDO S., ANGELINI G., BENEDETTI G., et al.: Major early complications from diagnostic and therapeutic ERCP: A prospective multicenter study. Gastrointest Endosc., 48 (1): 1-10, 2018.

13- MASCI E., TOTI G., MARIANI A., et al.: Complications of diagnostic and therapeutic ERCP: A prospective multicenter study. Am. J. Gastroenterol., 96 (2): 417-423, 2011.

14- IORGULESCU A., SANDU I., TURCU F. and IORDACHE N.: Post-ERCP acute pancreatitis and its risk factors. Journal of medicine and life. Mar., 15; 6 (1): 109, 2013.

15- Beger H.G., Rau B., Mayer J., et al.: Natural course of acute pancreatitis. World J. Surg., 21 (2): 130-135, 2017.

16- BUCHLER M.W., GLOOR B., MULLER C.A., et al.: Acute necrotising pancreatitis: Treatment strategy according to the status of infection. Ann. Surg., 232 (5): 619626, 2016. 


\section{كيفية معالجة المضاعفات الناتجة عن تصوير البنكرياس والقنوات الصفراوية بالتنظير الباطنى بالطريق الراجيع}

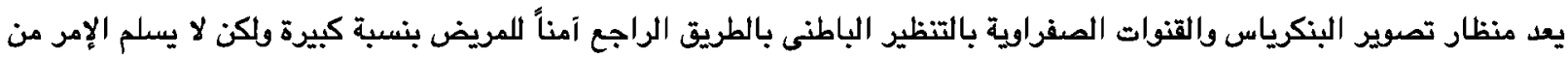

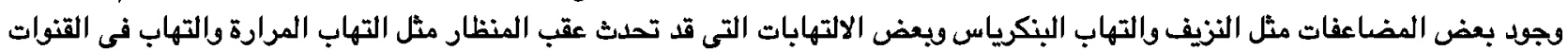

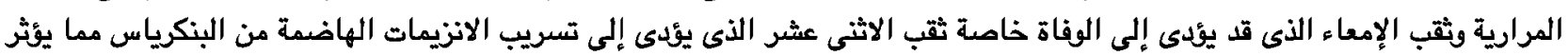

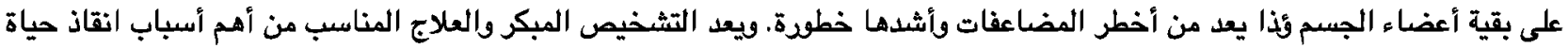
المريض.

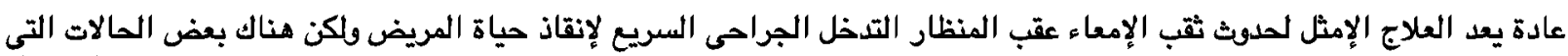

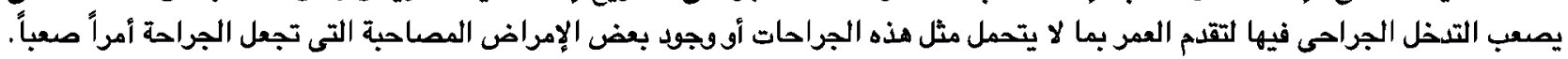
يمكن لمثل هذه الحالات التدخل لاصلاح الثقب عن طريق منظار القنوات المرارية ولكن يظل الحل الجراحى هو الامثل.

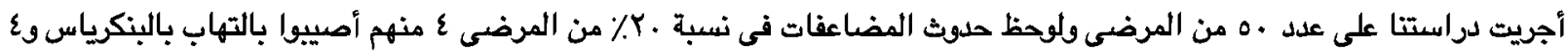

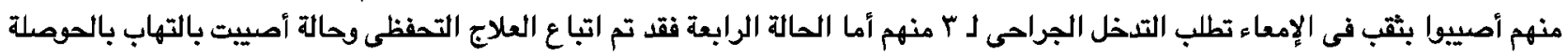
المرارية والحالة الاخيرة أصييت بالتهاب في القيات القنوات المرارية عقب المنظار.

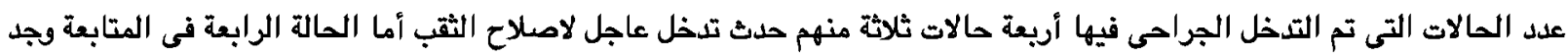

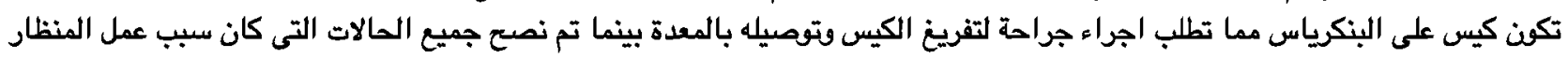
لهم وجو حصوات بالقناة المرارية ورجع ذلك لوجود التهاب حصوى بالمرارة باستئصال المرارة يعتبر المنظار ههم جداً وعالى الكفاءة و لكن الوعى الكامل بالمضاعفات هو وأول خطوة فى علاجها. 